\title{
Letters
}

To the Editor:

It is now a good half year since publication of your editorial, "Can Academic Librarians Afford College \& Research Libraries" (CRL, March 1971), and any effort to correct the conclusions drawn by some of your readers may now seem late indeed. Nevertheless, publication in your September issue of a selection of the more than eighty letters received in response to that call to arms now demands some clarification of the remarks I made in Los Angeles last January before the ALA Budget Assembly, for these were presumably the basis for your opening sentence ("Some people now serving on COPES and the ALA Publishing Board are seriously considering the abolition of divisional newsletters and the consolidation of divisional journals.").

This hearsay reference, undocumented by any reference to what was actually said in any meeting at Los Angeles, led into a discussion of how CRL is financed-a matter certainly of great import to all members of ACRL, and concerning which your remarks were entirely apt. My quarrel could only be with that unfortunately misleading opening sentence, for it placed your entire argument in the context of a presumed threat to the very existence of $C R L$. I am further dismayed now to see that even as late as the September CRL you did not see fit to clarify the issue. Since so many of your readers inferred from your editorial that the ALA Publishing Board had advocated abolition of $C R L$, it would seem only fair that you take pains to report what actually was said at Los Angeles.

You will recall that I pointed out to ACRL president Anne Edmonds in a letter on June 8,1971 , with a copy to you, that I knew of no one in any responsible position in ALA who had advocated abolition of $C R L$. I quoted to her then from my comments to the Budget Assembly, since they had not been reported in full. I am taking the liberty of quoting them here, for it seems important to have on record what actually was said with respect to the problems of funding newsletters and journals.

"Can the ALA continue to support the publishing of six division periodicals and eight newsletters? With the curtailing of allocations from Publishing Funds, some of our periodicals will be in even greater trouble than they have been, for production costs continue to increase, and prospects for increased advertising revenue are not good. Again, rather than consider conversion of even one newsletter to journal status, we need to question whether we can reasonably continue to sanction the many separate journals now being published by divisions, and to scrutinize even more closely the continued publication of all of the newsletters now being issued.

"This is a matter which must be of mutual concern to all of us in every unit of the ALA. We need to study the problem together with the several units to consider how we may best develop the means for satisfying the needs of all of us. We have no ready solutions for the problems created by mounting costs and diminished income. We do not have any sweeping proposals to make for restructuring the publishing programs of the many units of the ALA. This is a matter for all of us to consider together, and we shall be planning such mutual discussions of our problems.

"For our part, we are, for example, looking to the possibility of extending the newsletter potentialities of American Librariesto try to determine whether the current awareness functions of a number of ALA units can be more economically, and perhaps more effectively served through some centralization of this kind of publishing. There are other alternatives that we should consider such as the possibility of developing a consolidated newsletter which might 
be capable of providing for good communication for many of our units.

"Since American Libraries goes to all members of ALA, we should acknowledge, I think, that first priority in our allocations should be placed there. But if assistance cannot be offered direct to the several divisions in support of their publications, we should seek to assist them in other ways in satisfying their publishing needs. In this matter, the self-scrutiny of every unit in the ALA will be essential, for in the necessary curtailment of allocations for their journals and with prospects for reduced income, it will be necessary to effect some kind of reduction in the publishing program for every journal and newsletter now being issued by ALA units."

I shall appreciate your publishing these paragraphs in CRL if you can afford the space-recognizing that you do indeed have space problems under the present restriction on journal pages!

\section{Everett T. Moore}

Chairman, ALA Publishing Board

\section{To the Editor:}

Now that library budgets in general are reduced or, at best, remain about the same as last year, it should be increasingly evident that, if similar numbers of staff hours and amounts of material are expected as in the past, there are basically two ways to go -seek additional funds or engage in cooperative efforts.

Here in Utah we are becoming deeply committed to the latter philosophy. The Brigham Young University, Utah State, and the University of Utah are already interconnected with a daily delivery van service for interlibrary loans. This year, with the assistance of the state archivist's trained staff and equipment, we are having the card catalogs of each of these institutions' libraries microfilmed.

One thing leads to another. By the time the microfilming effort is completed next spring, we expect to immediately implement a broader interlibrary loans program, which will include all undergraduates. It will be based on the van, the microfilmed catalogs, and a do-it-yourself approach on the part of the patron, using simplified procedures to reduce costs.

Perhaps none of this is exactly new. What is unusual is that we have gone the cooperative route before, when budgets were fat, without success. Now that they are reduced, renewed interest is being experienced in cooperative programs. Lean budgets, then, seem to act as a catalyst in bringing libraries together. Like the man said-perhaps some good comes out of everything.

Oh yes - the theme of the Utah Library Association's meeting next March? "Cooperation," of course.

Cooperative efforts are nothing new, but fund raising must certainly be terra incognita for most librarians, and Mr. Eaton's "Fund Raising for University Libraries" in the September issue of $C R L$ could not have been better timed for the Marriott Library. We are now in the process of organizing deliberately to sell ourselves more effectively to both campus and off-campus communities through an invigorated public relations campaign. Part of that effort will include fund raising and, I can assure you, Eaton's sensible mapping of the terrain will be a primary guide. His article is just another indication to me that $C R L$, of all the ALA publications, consistently provides the best information to accomplish the job. As far as this writer is concerned-take it away and bye-bye ALA.

Gus Hanniball
Extension Librarian
Marriott Library
University of Utah
Salt Lake City

\section{To the Editor:}

It was, I suppose, to be expected that an engineer would adduce, in reply to Mr. Ellsworth Mason's report on computers, the hoary old fallacy that any machine or device is merely an extension of man and no more than a reflection and magnification of the man controlling it. The logical converse of this position is to claim that man is inferior to the motor car because he has not grown wheels. It is, one would have thought, perfectly obvious that man is not able to match the performance of his own 
products, which are of a totally different order of things. But neither is he subject to the same limitations. One of the great claims that have been made for the application of computers to library systems is that it forces us to make an analysis of the system in small steps which can be reduced to a binary choice. It follows from this that we know exactly what we are doing, and can instruct the computer to do the same thing. To reduce all human thought to this sort of process, as on-line computerized information retrieval systems are obliged to, is like asking us to make a conscious decision on which leg to move each time we take a step in walking. We do in fact adopt this practice sometimes, for example, in learning a complicated series of dance steps; but of course we are quickly able to transcend the formality of making a binarytype decision for each step as we master the skill and can control our bodily movements without the necessity for making a conscious decision each time.

Mason's onslaught was devastating precisely because it was based on his observation of real practice, and not on some hypothetical situation dreamed up in a computer laboratory, and totally unrelated to what actually happens in library and information services. Of course it was limited; so is every other single piece of research that Mr. Corbin could mention. But it was related to the real needs of users, and it must have cost the Council on Library Resources only the minutest fraction of what it has, over the years, disbursed for studies of computer systems that are equally limited, and some at least of which seem somehow to have vanished from sight.

Incidentally, what is "cutesy"? It is not in the Oxford English Dictionary. Presumably, it bears some relation to words like cute and cuteness, which are; but how would the computer handle this particular concept?

\section{J. Foskett Librarian University of London Institute of Education}

To the Editor:

Subject: A dry cough and a loud cry from the un-silent majority about "Legis- lative Naiveté of Librarians"; or, Dear God is anybody listening?

Librarians are not always knowledgeable about the intricacies and nuances of legislative processes and procedures. And sometimes, with our bodies inextricably enmeshed in our libraries' work, needs, problems, and pressures, we have forgotten, or lost sight of, the diplomatic approaches toward our goal of selling our managements, not necessarily our patrons, on the tasks we cannot perform without their assistance.

For over three and one-half years I worked for Bechtel Corporation's Power \& Industrial Division in their Washington office in Gaithersburg, Maryland. Every time the American Management Association, located in New York City, sent out notices that they were holding a week-long management course dealing with libraries, I sent copies to everyone in management. The cost was about $\$ 750$. Never, at least to my knowledge, did anyone of these men ever ask me about the course and its value to themselves and what it might do to help them understand the whole realm of libraries and librarianship. I went one step further and I supplied American Management Association the names of the men, and our company's address, so that they would get these notices directly. A few men would send the notice to me thinking that I would be interested in the circular, and that I would want to keep it for reference purposes.

Members of top management, who hold the purse strings, the life blood of the library, and future operational efficiency in their hands, do not usually make it a point to visit their libraries. Once a year they may stop in the library because their secretaries are away from their desks, or some special and immediate problem has arisen that urges them into the library compound. Otherwise they send their secretaries, who, very much like their bosses, don't know very much about libraries, and do not take too much interest in the libraries' operations.

We have instant coffee, instant tea, instant potatoes, and therefore, men of management expect instant librarianship. They see the public service area, and patrons using the libraries, and they assume that all 
is going well. If they do not know the staff very well, they may conclude, as many library users do, that everyone there is a professional librarian. Men of management rarely understand, and often do not care to take the time to understand, what goes on in the nonpublic service working areas: cataloging, acquisitions, etc.

Companies, just like the state governments, and the U.S. government agencies, are all publishers of a variety of materials. Everyone engaged in the writing, proofreading, printing, binding, and distribution aspects of any publication completely forgets that ultimately someone, somewhere, somehow, is going to want to keep a copy. The most obvious places are the libraries, those well-organized, overcrowded, overworked, sometimes out-of-date, and sophisticated warehouses of knowledge and information.

If we are going "to sell the case for librarianship to our colleagues in other disciplines" we will have to get to the hallowed halls of the highest and mightiest: the royal throne room of management. If management, who say they need and want libraries, desire to know what librarians can do for them, we must build a strong and attractive display of what we can, have, and will do for them. We might also point out what we have not been able to do, and exactly why.

Bechtel Corp. is listed in Engineering News-Record as the number one construction firm in the U.S. They have numerous volumes of standards, but none of them deal with libraries, library personnel, or anything to do with librarianship. They measure and calculate everything, except exactly why their loose-leaf reports have not been updated. They've spent more money for their personnel's air transportation all over the U.S. and the world than they have for books, libraries, and library personnel. At Bechtel my directions for operation came from the office in which I worked. There was no cooperative book purchasing or cataloging. There was never any evidence, or even hope, that we would have a bibliographic center at the San Francisco home office.

At Bechtel, and here in the Forrestal Building in Washington, D.C., there are a number of "illegal" or unofficially sanc- tioned libraries which have been allowed to flourish. They came into existence because the existing libraries in the building do not meet the existing needs of everyone housed here. It means that funds, space, and personnel are indirectly siphoned from the main sources. Management has its own kind of occupational blindness about libraries. Creating workshops for libraries may be interesting for librarians, but if we cannot get the members of top management, who are usually not librarians, to attend, we may consider that our time and efforts have been spent in the wrong direction.

Perhaps what we need is a library cooperative consulting service in Washington, D.C. and/or New York City and/or Chicago, etc., that is designed to "sell" librarianship to management. Top management could write, call, or personally visit the library cooperative consulting service for advice, information, pamphlets, or whatever it is that they seem to be interested in at the moment. It could be a combined effort of large library supply houses with displays, samples, and pamphlets as examples of what they should see and know about. Book companies could be represented. The library cooperative consulting service should be able to offer statistics, standards, architectural drawings, and down-to-earth concrete information and possible suggestions and solutions as to what to do in a given instance. It must, above all, be beautiful and inviting to anyone. It must be understood that this is not for actual selling and pressure, but for the presentation of facts for top managements' awareness. Perhaps a library of its own could be included.

My theme is this: If we cannot attract management, and members of the various legislative branches of governments to our causes and goals, by whatever wholesome and legitimate means we can, the wheels of librarianship will spin without much drive.

And I certainly agree with the statement that: "We certainly won't sell the case for librarianship talking to each other at ALA meetings."

Herbert M. E. Pastan

Chief Cataloger

Office of the Chief of Engincers Washington, D.C. 
To the Editor:

Kudos to Allan Hershfield and CRL for his editorial (September). Indeed, a librarian should ". . . become an integral, contributing member of social science research teams."

How does one find such a job? When such positions are announced I'll be the first to apply.

\section{Richard H. Dewey \\ Orientation Librarian \\ Sir George Williams University Montreal, Quebec, Canada}

\section{To the Editor:}

No matter how busy I am, I dip into $C R L$ the day it arrives in this building. There's always much of use, such as Eaton's "Fund Raising for University Libraries."

\section{Charles Dollen}

Knights of Columbus Memorial Library University of San Diego

San Diego, California

\section{To the Editor:}

Here is a response to all the responses re: abolishment and/or curtailment of CRL and CRL News.

While I agree with most of what has been said, particularly the salutary words for the journal and its editor, I am not for pouring out the baby with the bath water. In this case the baby is librarianship and the bath water then must of necessity be ALA. The water has, to be sure, been muddy lately, and is likely to remain so for some time. The unfortunate decision to have an "expert consultant" make a study of the whole mess instead of putting our own house in order will make it plum nasty, as we used to say in the South.

However, I seem to read between the lines in most of what your respondents have to say that "we academic librarians" are different kinds of animals and have little in common with those "other types who read American Libraries, heaven forbid. . . ." This is precisely what is wrong with us; this everlasting parochialism ("You don't understand my problem and I don't understand yours") has simply got to cease if we are ever going to do what we say we want to do, namely serve all the people with the kind of information they need. Who is going to stand up and shout that we are librarians first, and then we consider what kinds of libraries we are in?

That we need CRL and LRTS and School Libraries (and JOLA, too, I guess) is certain. Each does serve an important function, and cannot be abandoned. But we do need American Libraries (for which your respondents had such unkind words) as a unifying force among librarians. How to do this? Mel Voigt made a courageous start when he questioned seriously the amounts budgeted for administrative services and the like at headquarters. No one has had the courage to do this before, more of us need to. This is where the fat has to be trimmed; this is where a management study would be in order. Not in the services, such as publications, which the ALA provides, and with which headquarters has precious little to do.

They print the things, but unpaid editors and unpaid writers do most of the work. The real services which ALA provides are planned, debated, and completed in committee work; let us not forget this. It is not a "them and us" situation; we are the ones who make things go (or sit back and criticize, whichever. ..).

ALA headquarters is a secretariat which aids members. That is what it is supposed to be. It is also supposed to carry out the wishes of membership. Thus, we need to take a long, hard look at what is being done to carry out the wishes of members; if I specify that $\$ 5.00$ of my dues go to $C R L$ then no one, but no one has a right to change this and do something else with my money. If membership as a whole votes to do something else with my money, then I must bow to majority vote. But only then....

So let's put our efforts into straightening out things and making them better instead of withdrawing. If we withdraw, will someone please tell me what is being gained? Not strength, not money, not legislative support, not understanding of other libraries' problems - not presenting a united front when it comes to presenting a case 
before funders. We gain nothing, as far as I can see-and we lose a lot.

\section{(Mrs.) Brigitte L. Kenney \\ Drexel University \\ Philadelphia, Pennsylvania}

P.S.: I was going to write a rebuttal to Ellsworth Mason, but this has been done well by others. I can add nothing; Dr. Barnett made my main point that Mr. Mason is guilty of being dogmatic, which is what he accuses the automators of. . . . And that doesn't help the least bit. I am volunteering to send Mason a list of ongoing, successful, money-saving automated library operations which he should visit on his next foundation-sponsored jaunt-he missed them this time around.

\section{To the Editor:}

Lubans (CRL 32:482; Nov. 1971) feels that the figures for my in-house samples are low. He may be right and there may be good reasons for it. But this is not the issue. There is no reason to assume that the correlations between in and out would be any different if the in-house figures were larger. The ratio of out-to-in could be much different without necessarily affecting the size of the correlations, which may be the only issue here if there is an issue.

Several conditions might account for the low in-house samples. His studies included journal counts; mine did not. Different con- ditions in the different libraries-lighting, available seating, air conditioning, demands of the curriculum, whether users are commuters (Lubans mentions several more)all might affect the magnitude of in- or outof library use. But these conditions were not a part of the experiment, although they certainly are legitimate areas of concern, and their effects certainly ought to be known.

I agree that a definition of "use" would be interesting. Certainly, one is needed. In my paper I did make some assumptions about use, but did not attempt a complete definition. I now feel that many, if not most, books taken from open stacks and left around on tables may not reflect "use" at all. Rather, such books may reflect nothing more than a quick perusal to ascertain whether a book has any useful information. If it does, the book is more likely to be checked out; if not, then more likely to be left on tables. This hypothesis should be tested. (In a forthcoming paper, I have tested the hypothesis that if a book matches a profile of the university curriculum, it will have a greater probability of being checked out.)

A good definition of "use," if "use" is what we want to define, would certainly help to refine our understanding of library effectiveness.

William E. McGrath School of Library Science Syracuse University Syracuse, New York 